\title{
AKRUAL
}

Jurnal Akuntansi

http://journal.unesa.ac.id/index.php/aj

\section{PERAN PERBANKAN SYARIAH TERHADAP PERTUMBUHAN EKONOMI SEKTOR RIIL DI INDONESIA}

\author{
Linda Tamim Umairoh Hasyim \\ Universitas Negeri Surabaya \\ lindatamim0gmail.com
}

\begin{abstract}
Abstrak
Penelitian ini bertujuan untuk menguji dan menganalisis peran perbankan syariah terhadap pertumbuhan ekonomi sektor riil di Indonesia. Peran perbankan syariah diukur menggunakan dana pihak ketiga (DPK) dan pembiayaan yang diberikan (PYD), sedangkan pertumbuhan ekonomi sektor riil diukur dengan produk domestik bruto (PDB) .Penelitian ini menggunakan sebanyak 387 data time series dari statistik perbankan syariah dan statistik ekonomi dan keuangan Indonesia selama periode penelitian 20082016 dengan data bulanan sebagai basis datanya. Data dianalisis menggunakan metode analisis regresi linier berganda.Penelitian ini menemukan bahwa sektor perbankan syariah mendorong terjadinya pertumbuhan ekonomi sektor riil di Indonesia.
\end{abstract}

Kata Kunci: Dana Pihak Ketiga, Pembiayaan yang Diberikan, Produk Domestik Bruto, Sektor Riil.

\section{PENDAHULUAN}

Kemunculan perbankan syariah di dunia diawali dengan Mit Ghamr Local Saving pada 1963 yang kemudian diambil alih oleh Pemerintah Mesir menjadi Nasser Social Bank pada 1972. Perkembangan perbankan syariah di Timur Tengah kemudian berlanjut ke Eropa, Swiss, Denmark, serta negara-negara di Asia Tenggara yang mayoritas masyarakatnya beragama Islam. Di Malaysia, bank syariah pertama kali didirikan pada 1982, sedangkan di Indonesia baru sembilan tahun sesudahnya yaitu 1991 (Nurhayati dan Wasilah, 2015:3).

Perkembangan perbankan syariah di negara-negara Islam kemudian diikuti oleh Indonesia. Lahirnya perbankan syariah di Indonesia diawali dengan berdirinya Bank Muamalat Indonesia (BMI) pada 1991. Sebelumnya, di Indonesia juga telah didirikan lembaga-perbankan nonbank yang dalam kegiatannya menerapkan sistem syariah. Pemerintah kemudian membuat peraturan untuk pelaksanaan bank syariah melalui UU No. 7 tahun 1992 tentang perbankan dan dijelaskan pada PP No. 72 tahun 1992. Berdasarkan Statistik Perbankan Syariah hingga November 2016, jumlah Bank Umum Syariah yang tercatat di Indonesia 
sebanyak 13 bank, 21 Unit Usaha Syariah dan 164 Bank Pembiayaan Rakyat Syariah.

Indonesia merupakan negara yang memiliki jumlah muslim terbesar di dunia. Berdasarkan data yang dirilis oleh Badan Pusat Statistik melalui hasil sensus penduduk 2010 menurut wilayah dan agama yang dianut di Indonesia dapat diketahui bahwa jumlah penduduk muslim dari provinsi Aceh sampai dengan provinsi Papua adalah sebesar 207.176.162 orang. Namun apabila dilihat dari segi pangsa pasar industri keuangan syariah nasional, hasilnya masih jauh tertinggal dibandingkan Malaysia yaitu sebesar 5,3\%. Malaysia, sebagai salah satu negara yang memiliki jumlah mayoritas penduduk muslim yaitu $64 \%$ atau sekitar 20.389.632 orang, pangsa pasar industri keuangan syariah nasionalnya sebesar 40$50 \%$ dari total aset perbankan nasionalnya.

Secara umum, fungsi utama bank adalah sebagai financial intermediary atau penghimpun dana dari masyarakat yang memiliki dana berlebih dan menyalurkannya kembali kepada masyarakat yang membutuhkan dana untuk berbagai tujuan (Budisantoso dan Nuritomo, 2015:9). Kemampuan bank dalam menyalurkan pembiayaan sangat tergantung pada kemampuannya untuk memobilisasi dana pihak ketiga dari masyarakat. Kondisi ini bergantung pada tingkat persaingan di kalangan industri perbankan, baik perbankan syariah maupun konvensional dalam mengumpulkan dana pihak ketiga dan menyalurkannya ke sektor bisnis yang menguntungkan.

Pada masa krisis tahun 1997-1998 bank syariah dapat membuktikan ketahanannya walaupun mengalami penurunan profit yang didapat. Bank Muamalat yang pada dasarnya menggunakan prinsip bagi hasil, selamat dari krisis akibat produk-produknya yang variatif, seperti contoh produk pembiayaan Murabahah yang tidak terpengaruh oleh fluktuasi BI rate, sehingga sektor riil yang menggunakan pembiayan ini juga selamat dari dampak buruk kenaikan BI rate. Hal berbeda dialami oleh perbankan konvensional, krisis ekonomi yang melanda pada saat itu menyebabkan 16 bank dilikuidasi, berikutnya 38 bank, kemudian 55 bank masuk kategori BTO (Bank Take Over) dalam pengawasan Badan Penyehatan Perbankan Nasional (BPPN). 
Perbankan syariah diharapkan dapat menggerakkan perekonomian nasional yang terdiri dari sektor riil dan sektor keuangan. Definisi sektor riil menurut pendekatan produksi adalah jumlah nilai tambah atas barang dan jasa yang dihasilkan oleh berbagai unit produksi di wilayah suatu negara dalam jangka waktu tertentu (biasanya satu tahun). Unit produksi antara lain terdiri dari pertanian, kehutanan dan perikanan; pertambangan dan penggalian; industi pengolahan; pengadaan listrik dan; pengadaan air, pengelolaan sampah, limbah dan daur ulang; konstruksi; perdagangan besar dan eceran, reparasi mobil dan sepeda motor; transportasi dan pergudangan; penyediaan akomodasi makan dan minum; informasi dan komunikasi; jasa keuangan dan asuransi; realestate; jasa perusahaan; administrasi pemerintahan, pertahanan dan jaminan social wajib; jasa pendidikan; jasa kesehatan dan kegiatan lainnya; serta jasa lainnya.Setiap sektor tersebut dirinci lagi menjadi sub-sub sektor.

Bank Indonesia selaku regulator, memberikan dorongan untuk perkembangan perbankan syariah dalam sektor riil. Hal ini dikarenakan produk pembiayaan pada bank syariah harus menggunakan underlying transaksi. Sehingga dampak yang ditimbulkan lebih nyata dalam mendorong pertumbuhan ekonomi.Selain itu produk bank syariah tidak bersifat gharar (spekulatif) sehingga lebih kuat daya tahannya terhadap krisis keuangan global. Prinsip bagi hasil (profit-loss sharing) memiliki manfaat yang baik dan adil bagi pihak pemilik dana, pengusaha maupun pihak bank tersebut.

Bank syariah sebagai lembaga intermediasi, menghimpun dana dari masyarakat untuk kemudian dana yang terkumpul tersebut diinvestasikan pada sektor ekonomi yang diperbolehkan secara syariah. Dana yang dihimpun oleh bank syariah disebut dana pihak ketiga. Dana pihak ketiga bersumber dari simpanan dalam bentuk giro, deposito berjangka dan tabungan.Dana Pihak Ketiga (DPK) merupakan salah satu indikator ekonomi makro.Dana Pihak Ketiga digunakan sebagai dasar penetapan Giro Wajib Minimum. Giro Wajib Minimum (GWM) adalah simpanan minimum yang wajib dipelihara oleh Bank dalam bentuk saldo Rekening Giro pada Bank Indonesia yang besarnya ditetapkan oleh Bank Indonesia sebesar persentase tertentu dari DPK. GWM merupakan 
instrumen moneter atau makro prudensial untuk mengatur uang beredar di masyarakat yang secara langsung berpengaruh terhadap indeks inflasi. Sesuai dengan ketetapan 16 Maret 2016, saat ini besaran GWM Primer adalah 6,5\% dari DPK.

Dana yang dihimpun dari pihak ketiga kemudian disalurkan pada penerima pembiayaan, yaitu pertanian, perburuan dan kehutanan; perikanan; pertambangan dan penggalian; industri pengolahan; listrik, gas, dan air; konstruksi; perdagangan besar dan eceran; penyediaan akomodasi dan penyediaan makan minum; perantara keuangan; real estate, usaha persewaan dan jasa perusahaan; administrasi pemerintah, pertahanan dan jaminan sosial wajib; jasa pendidikan; jasa kesehatan dan kegiatan sosial; jasa kemasyarakatan, sosial budaya, hiburan, dan perorangan lainnya; jasa yang melayanirumah tangga; kegiatanjasa lainnya.

Kassim (2016) di Malaysia mengungkapkan bahwa kegiatan pembiayaan bank syariah membuat kontribusi yang signifikan terhadap kegiatan ekonomi riil baik dalam jangka pendek dan panjang, dengan kontribusi jangka panjang yang kuat. Selain itu, penelitian dari Yusof dan Bahlous (2013) juga mengungkapkan perbankan Islam berkontribusi terhadap pertumbuhan ekonomi baik dalam jangka panjang dan jangka pendek untuk kedua negara GCC dan negara-negara yang dipilih Asia Timur. Namun dalam jangka pendek, perbankan syariah memberikan kontribusi lebih terhadap pertumbuhan ekonomi di Malaysia dan Indonesia dibandingkan dengan negara-negara GCC. Berdasarkan latar belakang diatas, peneliti bermaksud untuk menguji pengaruh peranan bank syariah terhadap pertumbuhan ekonomi sektor riil. Peranan bank syariah diukur dengan dana pihak ketiga dan pembiayaan yang diberikan, sedangkan pertumbuhan ekonomi sektor riil diukur dengan Produk Domestik Bruto (PDB).

\section{KAJIAN PUSTAKA}

\section{Teori Pertumbuhan Ekonomi}

Isu tentang keuangan dan pertumbuhan ekonomi telah dipaparkan sejak abad ke 19 oleh Joseph A. Schumpeter tentang urgensi sistem perbankan dan pertumbuhan tingkat pendapatan nasional dalam pembangunan ekonomi melalui identifikasi dan pembiayaan pada sektor investasi yang produktif (Schumpeter, 1912). Dalam 
teorinya, Schumpeter menyebutkan beberapa hipotesis tentang hubungan sektor keuangan dengan pertumbuhan ekonomi, yaitu: 1) Supply-leading view (keuangan adalah faktor penentu pertumbuhan ekonomi), 2) Demand-following view (keuangan mengikuti pertumbuhan ekonomi), 3) The bidirectional causality view (hubungan saling mempengaruhi antara keuangan dan pertumbuhan), dan 4) The independent hypothesis (keuangan dan pertumbuhan tidak saling berhubungan).

\section{Teori Fungsi Produksi}

Fungsi produksi menunjukkan sifat hubungan diantara faktor-faktor produksi dan tingkat produksi yang dihasilkan. Faktor-faktor produksi, dapat dibedakan menjadi empat golongan, yaitu jumlah stok modal, jumlah tenaga kerja, kekayaan alam (tanah), dan tingkat teknologi yang digunakan.

Tingkat produksi suatu barang tergantung kepada jumlah modal, jumlah tenaga kerja, jumlah kekayaan alam, dan tigkat teknologi yang digunakan. Jumlah produksi yang berbeda-beda dengan sendirinya akan memerlukan berbagai faktor produksi tersebut dalam jumlah yang berbeda pula. Selain itu, untuk satu tingkat produksi tertentu, dapat pula digunakan gabungkan faktor produksi yang berbeda. Misalnya untuk memproduksi sejumlah hasil pertanian tertentu, perlu digunakan tanah yang lebih luas apabila bibit unggul dan pupuk tidak digunakan, tetapi luas tanah dapat dikurangi apabila pupuk dan bibit unggul serta teknik bercocok tanam modern digunakan. Dengan membandingkan berbagai gabungan faktor-faktor produksi untuk menghasilkan sejumlah barang tertentu dapatlah ditentukan gabungan faktor produksi yang paling ekonomis untuk memproduksi sejumlah barang tersebut.

\section{Teori Stewardship}

Teori Stewardship adalah teori yang dicetuskan oleh Donaldson dan Davis pada tahun 1991, teori ini menggambarkan situasi dimana para manajer tidaklah termotivasi oleh tujuan-tujuan individu tetapi lebih ditujukan pada sasaran hasil utama mereka untuk kepentingan organisasi, sehingga terdapat hubungan yang kuat antara kepuasan dan kesuksesan organisasi. Kesuksesan organisasi menggambarkan maksimalisasi utilitas kelompok principals dan manajemen. 
Maksimalisasi utilitas kelompok ini pada akhirnya akan memaksimumkan kepentingan individu yang ada dalam kelompok organisasi tersebut. Stewardship teori dalam penelitian ini dapat dipahami dalam pemberian pembiayaan dalam bentuk akad murabahah kepada para nasabah. Bank syariah sebagai prinsipal yang mempercayakan nasabah sebagai steward atas dana atau aset yang idealnya untuk mengakomodasi semua kepentingan bersama antara principal dan steward.

\section{Bank}

Bank didefinisikan oleh Undang-undang Nomor 10 tahun 1998 tentang Perubahan Atas Undang-undang Nomor 7 tahun 1992 tentang Perbankan sebagai badan usaha yang menghimpun dana dari masyarakat dalam bentuk simpanan dan menyalurkannya kepada masyarakat dalam bentuk kredit dan atau bentuk-bentuk lainnya dalam rangka menigkatkan taraf hidup rakyat banyak. Penggolongan bank tidak hanya berdasarkan jenis kegiatan usahanya, melainkan juga mencakup bentuk badan hukumnya, pendirian dan kepemilikannya, target pasarnya, fungsinya, status kepemilikannya, kegiatan operasionalnya, penciptaan uang giral, sistem organisasi, dan letak geografis. Ditinjau dari segi imbalan atau jasa atas penggunaan dana, baik simpanan maupun pinjaman, bank dapat dibedakan menjadi:

1) Bank Konvensional, yaitu bank yang dalam aktivitasnya, baik penghimpunan dana maupun dalam rangka penyaluran dananya, memberikan dan mengenakan imbalan berupa bunga atau sejumlah imbalan dalam persentase tertentu dari dana untuk suatu periode tertentu. Persentase tertentu ini biasanya ditetapkan per tahun.

2) Bank Syariah, yaitu bank yang dalam aktivitasnya, baik penghimpunan dana maupun dalam rangka penyaluran dananya memberikan dan mengenakan imbalan atas dasar prinsip syariah yaitu jual beli dan bagi hasil.

\section{Riba}

Menurut Undang-undang No. 21 Tahun 2008 tentang Perbankan Syariah, riba merupakan penambahan pendapatan secara tidak sah (batil) antara lain dalam transaksi pertukaran barang sejenis yang tidak sama kualitas, kuantitas, dan waktu 
penyerahan (fadhl), atau dalam transaksi pinjam-meminjam yang mempersyaratkan Nasabah Penerima Fasilitas mengembalikan dana yang diterima melebihi pokok pinjaman karena berjalannya waktu (nasi'ah).

\section{Dana Pihak Ketiga}

Berdasarkan Pasal 1 No. 20 Undang-undang No. 21 Tahun 2008, dana pihak ketiga merupakan dana yang dipercayakan oleh nasabah kepada Bank Syariah dan/atau UUS berdasarkan akad wadi'ah atau akad lain yang tidak bertentangan dengan prinsip syariah dalam bentuk giro, tabungan, atau bentuk lainnya yang dipersamakan dengan itu. Dalam dunia perbankan, dana pihak ketiga terdiri dari simpanan giro (demand deposit), simpanan tabungan (saving deposit), dan simpanan deposito (time deposit).

\section{Pembiayaan yang Diberikan}

Dalam masyarakat Indonesia, selain dikenal istilah utang-piutang, juga dikenal istilah kredit dalam perbankan konvensional dan istilah pembiayaan dalam perbankan syari'ah. Berdasarkan Undang-undang No. 10 Tahun 1998 tetang Perbankan, pembiayaan berdasarkan prinsip syariah adalah penyediaan uang atau tagihan yang dipersamakan dengan itu berdasarkan persetujuan atau kesepakatan antara bank dengan pihak lain yang mewajibkan pihak yang dibiayai untuk mengembalikan uang atau tagihan tabungan setelah jangka waktu tertentu dengan imbalan atau bagi hasil.

\section{Produk Domestik Bruto (PDB)}

Salah satu indikator penting untuk mengetahui kondisi ekonomi di suatu negara dalam suatu periode tertentu adalah data Produk Domestik Bruto (PDB), baik atas dasar harga berlaku maupun atas dasar harga konstan. PDB pada dasarnya merupakan jumlah nilai tambah yang dihasilkan oleh seluruh unit usaha dalam suatu negara tertentu, atau merupakan jumlah nilai barang dan jasa akhir yang dihasilkan oleh seluruh unit ekonomi. Bagi para ekonom, ahli statistika, dan wartawan, perhitungan pendapatan nasional memberikan informasi yang 
mendalam yang dapat digunakan untuk memproyeksi pertumbuhan dan pembangunan ekonomi.

PDB merupakan nilai moneter dari seluruh produksi barang jadi yang diproduksi dalam sebuah negara pada periode tertentu. Dalam ekonomika makro, pengertian PDB terbagi menjadi dua (Mankiw, 2007), yaitu: seluruh pengeluaran untuk barang jadi dan jasa yang diproduksi dalam negeri atau seluruh pendapatan yang dihasilkan oleh seluruh pemilik faktor produksi dalam negeri. Badan Pusat Statistik menggunakan tiga pendekatan dalam menghitung PDB, yaitu pendekatan produksi, pendekatan pengeluaran dan pendekatan pendapatan. Pada pendekatan produksi, PDB adalah jumlah nilai tambah atas barang dan jasa yang dihasilkan oleh berbagai unit produksi di wilayah suatu negara dalam jangka waktu tertentu (biasanya satu tahun). Unit-unit produksi tersebut dalam penyajian ini dikelompokkan menjadi 17 lapangan usaha (sektor) yaitu: pertanian, kehutanan dan perikanan; pertambangan dan penggalian; industri pengolahan; pengadaan listrik dan; pengadaan air, pengelolaan sampah, limbah dan daur ulang; konstruksi; perdagangan besar dan eceran, reparasi mobil dan sepeda motor; transportasi dan pergudangan; penyediaan akomodasi makan dan minum; informasi dan komunikasi; jasa keuangan dan asuransi; real estate; jasa perusahaan; administrasi pemerintahan, pertahanan dan jaminan sosial wajib; jasa pendidikan; jasa kesehatan dan kegiatan lainnya; jasa lainnya.

\section{Pengaruh dana pihak ketiga yang dikumpulkan oleh bank syariah terhadap pertumbuhan ekonomi sektor riil}

Dana Pihak Ketiga Hasil Penelitian Kassim (2016) di Malaysia menunjukkan bahwa aspek pembiayaan dalam efek jangka panjang terbukti lebih kuat dari jangka pendek, sehingga bank perlu untuk menyeimbangkan dana mereka. Berdasarkan uraian di atas dapat ditarik hipotesis sebagai berikut:

\section{$\mathrm{H}_{1}$ : Dana pihak ketiga yang dikumpulkan oleh bank syariah berpengaruh terhadap pertumbuhan ekonomi sektor riil}


Pengaruh pembiayaan yang diberikan bank syariah terhadap pertumbuhan ekonomi sektor riil

Hasil penelitian sebelumnya menunjukkan adanya pengaruh antara pembiayaan yang diberikan bank syariah terhadap pertumbuhan ekonomi sektor riil.Kassim (2016) mengungkapkan bahwa pembiayaan bank syariah di Malaysia membuat kontribusi yang signifikan terhadap kegiatan ekonomi riil baik dalam jangka pendek maupun jangka panjang, dengan kontribusi jangka panjang yang kuat. Berdasarkan uraian di atas dapat ditarik hipotesis sebagai berikut:

$\mathrm{H}_{2}$ : Pembiayaan yang diberikan bank syariah berpengaruh positif terhadap pertumbuhan ekonomi sektor riil

\section{METODE PENELITIAN}

Jenis penelitian ini merupakan penelitian dengan metode kuantitatif untuk menguji hipotesis atau dalam menjawab rumusan masalah. Penelitian ini menggunakan data time series selama kurun waktu 2008-2016 dengan data bulanan sebagai basis datanya. Data-data tersebut diperoleh dari Statistik Perbankan Syariah (SPS) yang diterbitkan oleh Otoritas Jasa Keuangan serta Statistik Ekonomi dan Keuangan Indonesia (SEKI).

\section{Variabel Penelitian dan Definisi Operasional Variabel}

Variabel dependen dalam penelitian ini adalah Produk Domestik Bruto (PDB) harga konstan (riil). PDB harga konstan (riil) dapat digunakan untuk menunjukkan laju pertumbuhan ekonomi secara keseluruhan atau setiap sektor dari tahun ke tahun. Data terkait PDB diperoleh dari Statistik Ekonomi dan Keuangan Indonesia (SEKI) melalui situs Bank Indonesia (www.bi.go.id). Data yang digunakan adalah data time series triwulan periode 2008-2016.

Berdasarkan Undang-undang No. 21 Tahun 2008, dana pihak ketiga merupakan dana yang dipercayakan oleh nasabah kepada Bank Syariah dan atau UUS berdasarkan akad wadi'ah atau akad lain yang tidak bertentangan dengan prinsip syariah dalam bentuk giro, tabungan, atau bentuk lainnya yang dipersamakan dengan itu. Dalam dunia perbankan, dana pihak ketiga terdiri dari 
simpanan giro (demand deposit), simpanan tabungan (saving deposit), dan simpanan deposito (time deposit). Data diperoleh dari Statistik Perbankan Syariah melalui situs Otoritas Jasa Keuangan (www.ojk.go.id).Data yang digunakan adalah daa time series triwulan periode 2008-2016.

Undang-undang Perbankan No. 10 Tahun 1998, pembiayaan adalah penyediaan uang atau tagihan yang dapat dipersamakan dengan itu, berdasarkan persetujuan atau kesepakatan antara bank dengan pihak lain yang mewajibkan pihak yang dibiayai untuk mengembalikan uang atau tagihan tersebut setelah jangka waktu tertentu dengan imbalan atau bagi hasil. Pembiayaan tersebut terdiri dari transaksi bagi hasil dalam bentuk mudharabah dan musyarakah; transaksi sewa-menyewa dalam bentuk ijarah atau sewa beli dalam bentuk ijarah muntahiya bittamlik; transaksi jual beli dalam bentuk piutang murabahah, salam, dan istishna'; transaksi pinjam meminjam dalam bentuk piutang qardh; dan transaksi sewa-menyewa jasa dalam bentuk ijarah untuk transaksi multijasa. Data diperoleh dari Statistik Perbankan Syariah melalui situs Otoritas Jasa Keuangan (www.ojk.go.id).Data yang digunakan adalah daa time series triwulan periode 2008-2016.

\section{HASIL}

Tabel uji statistik deskriptif, tabel 1 menunjukkan sebanyak 387 data yang akan digunakan dalam penelitian ini. Berdasarkan hasil perhitungan tersebut, untuk variabel dana pihak ketiga (DPK) memiliki nilai terendah sebesar Rp29 triliun yang terdapat pada data SPSS kuartal 1 tahun 2008 dan nilai tertinggi adalah Rp279 triliun pada kuartal 4 tahun 2016. Dana Pihak Ketiga memiliki nilai ratarata sebesar Rp150,106 triliun dan standar deviasi sebesar Rp Rp80,065 triliun.

Variabel pembiayaan yang diberikan (PYD) memiliki nilai terendah sebesar Rp1 miliar yang terdapat pada kuartal 3 tahun 2016 sektor badan internasional dan badan ekstra internasional lainnya. Nilai tertinggi dana pihak ketiga sebesar Rp79,073 triliun yang terdapat pada kuartal 2 tahun 2014 sektor jasa dunia usaha. Pembiayaan yang diberikan memiliki nilai rata-rata sebesar Rp8,007 triliun dan nilai standar deviasi sebesar Rp10,672 trilun. 
Variabel kontrol nilai transaksi perdagangan di pasar saham (STOCK) memiliki nilai terendah sebesar 0,1288 yang terdapat pada kuartal 3 tahun 2015 . Nilai tertinggi nilai transaksi perdagangan di pasar saham sebesar 0,7006 yang terdapat pada kuartal 2 tahun 2013. STOCK yang diberikan memiliki nilai ratarata sebesar 0,3565 dan nilai standar deviasi sebesar 0,1752 .

Variabel produk domestik bruto (PDB) memiliki nilai terendah sebesar Rp1,689 triliun yang terdapat pada kuartal 1 tahun 2014 sektor pengadaan air, pengolahan sampah, limbah dan daur ulang. Nilai tertinggi produk domestik bruto sebesar Rp511,699 triliun yang terdapat pada kuartal 3 tahun 2016 sektor industri pengolahan. Produk domestik bruto memiliki nilai rata-rata sebesar Rp100,492 triliun dan nilai standar deviasi sebesar Rp100,825 triliun.

Berdasarkan uji normalitas tabel 2 menunjukkan bahwa data berdistribusi secara normal karena memiliki nilai signifikansi lebih besar dari 0, 05 yaitu 0,176. Berdasarkan uji Mltikolinearitas tabel 3 menunjukkan bahwa tidak terjadi multikolinearitas antar variabel independen dalam model regresi dikarenakan semua variabel independen menunjukkan nilai tolerance lebih besar dari 0,10 dan Variance Inflation Factor (VIF) lebih kecil dari 10,00. Berdasarkan uji autokorelasi, tabel 4 menunjukkan bahwa nilai test adalah 0,02670 dengan probabilitas 0,412 signifikansi 0,05 yang berarti residual tersebut sudah random dan tidak terjadi autokorelasi antar variabel residual. Sedangkan berdasarkan uji hipotesis, tabel 5 menunjukkan bahwa model regresi tidak mengandung adanya heteroskedastisitas karena probabilitas signifikansi semua variabel independen di atas tingkat kepercayaan 0,05.

\section{Pengujian hipotesis menggunakan model regresi:}

$$
P D B_{\mathrm{it}}=\alpha+\beta_{1} D P K_{\mathrm{it}}+\beta_{2} P Y D_{\mathrm{it}}+\varepsilon
$$

Uji $\mathrm{R}^{2}$ atau Koefisien Determinasi pada tabel 6 menunjukkan nilai Adjusted $R$ Square adalah 0,684 yang berarti 68,4\% PDB atau pertumbuhan ekonomi bisa dijelaskan oleh variabel independen yang terdiri dari dana pihak ketiga, pembiayaan yang diberikan, dan nilai transaksi perdagangan di pasar saham dan selebihnya $(100 \%-68,4 \%=31,6 \%)$ dijelaskan oleh variabel independen yang lain. 
Uji Signifikansi atau Pengaruh Simultan (Uji Statistik F) pada tabel 7 menunjukkan nilai $\mathrm{F}$ hitung sebesar 131,107 dengan signifikansi jauh lebih kecil dari 0,05 yaitu 0,000 yang berarti model regresi dapat digunakan untuk memprediksi PDB (Pertumbuhan Ekonomi) sehingga bisa diartikan bahwa PDB (Pertumbuhan Ekonomi) secara bersama-sama dipengaruhi oleh DPK, PYD, dan STOCK. Uji Signifikansi Parameter Individual (Uji Statistik t) pada tabel 8 menunjukkan bahwa ketiga variabel independen yaitu DPK, PYD dan STOCK mempunyai nilai signifikansi 0,000 yang jauh lebih rendah dari 0,05 . Hal ini menunjukkan bahwa kedua variabel (DPK dan PYD) berpengaruh positif dan variabel kontrol STOCK berpengaruh negatif.

\section{PEMBAHASAN}

\section{Pengaruh Dana Pihak Ketiga terhadap Pertumbuhan Ekonomi Sektor Riil di}

\section{Indonesia}

Hasil pengujian menunjukkan bahwa dana pihak ketiga berpengaruh positif terhadap pertumbuhan ekonomi sektor riil, yang artinya semakin tinggi dana pihak ketiga maka terjadi pula kenaikan pada pertumbuhan ekonomi sektor riil. Dana pihak ketiga merupakan dana nasabah yang dipercayakan kepada Bank Syariah dan/ atau Unit Usaha Syariah dengan akad wadi'ah atau akad lain yang sesuai dengan prinsip syariah dalam bentuk tabungan, giro, atau bentuk lain yang bisa disamakan dengan hal tersebut.

Hasil penelitian atas dana pihak ketiga berpengaruh terhadap pertumbuhan ekonomi sesuai dengan teori Schumpeter (1912) yang menyatakan bahwa financeled growth atau biasa disebut supply-leading hypothesis memperlihatkan hubungan penawaran antara sektor keuangan dengan pertumbuhan ekonomi. Teori ini menyatakan bahwa sektor keuangan mendorong pertumbuhan ekonomi. Sektor keuangan dalam hal ini perbankan syariah selaku perantara keuangan berfungsi sebagai penyalur dana dari pihak yang memiliki kelebihan dana kepada pihak yang membutuhkan dana melalui sumber-sumber pendanaan yang efisien yang kemudian akan menggerakkan sektor-sektor ekonomi dan memacu pertumbuhan ekonomi. Fase dan Abma (2013) menyebutkan bahwa pertumbuhan sektor keuangan berpengaruh terhadap pertumbuhan ekonomi. Horrison et al. (1999) 
dalam penelitiannya menjelaskan bahwa fungsi intermediasi lembaga sektor keuangan akan mendorong pertumbuhan ekonomi. Hal ini dikarenakan akan mengurangi biaya dalam penilaian proyek. Apabila jumlah proyek meningkat dalam perekonomian yang bertumbuh, maka pihak bank akan masuk ke dalam pasar sebagai bentuk aktivitas bank dan menambah keuntungan.

Pembiayaan yang diberikan oleh bank syariah berdasarkan jenis pengguna dan kategori usaha salah satunya adalah UMKM (Usaha Mikro Kecil Menengah). Berdasarkan data dari Statistik Perbankan Syariah tahun 2016, total modal kerja dan investasi yang diberikan oleh bank syariah dan unit usaha syariah kepada UMKM sebesar Rp54.530miliar. Walaupun pembiayaan yang diberikan kepada UMKM lebih rendah dari pembiayaan yang diberikan kepada non UMKM dan dengan total nasabah 18juta jiwa yang hanya $8,94 \%$ dari total penduduk muslim di Indonesia, namun sudah berpengaruh terhadap pertumbuhan ekonomi sebesar $68,4 \%$. Jadi apabila seluruh penduduk muslim di Indonesia yang berjumlah 207juta jiwa menanamkan dananya ke bank syariah, dapat kita bayangkan betapa pesatnya perekonomian kita.

Akan tetapi, untuk mendorong minat masyarakat dalam menginvestasikan dananya melalui bank syariah, perlu disadari bahwa masyarakat tersebut harus lebih dahulu percaya bahwa bank syariah mampu merealisasikan tujuan-tujuan investasinya. Belum adanya kepercayaan ini membuat banyak masyarakat menahan diri dalam berinvestasi melalui bank syariah. Ketersediaan informasi yang meyakinkan nasabah terhadap kemampuan bank syariah adalah salah satu alat untuk mengembangkan kepercayaan masyarakat. Sumber informasi tersebut berasal dari laporan keuangan bank syariah yang disiapkan sesuai dengan PSAK. Selain itu karena masih dalam tahap awal pengembangan, pemahaman sebagian masyarakat mengenai sistem dan prinsip perbankan syariah masih belum tepat. Pada dasarnya, sistem ekonomi syariah dengan jelas melarang adanya praktik riba (bunga). Namun adanya perbedaan karakteristik produk bank konvensional dengan bank syariah telah menimbulkan adanya keengganan bagi pengguna jasa perbankan. Keengganan tersebut antara lain disebabkan oleh hilangnya kesempatan mendapatkan penghasilan tetap berupa bunga dari simpanan. Oleh 
sebab itu, perlu disosialisasikan bahwa penempatan dana pada bank syariah juga dapat memberikan keuntungan finansial yang kompetitif.

\section{Pengaruh Pembiayaan yang diberikan terhadap Pertumbuhan Ekonomi Sektor Riil di Indonesia}

Hasil penelitian menunjukkan bahwa pembiayaan yang diberikan berpengaruh positif terhadap pertumbuhan ekonomi sektor riil yang artinya semakin besar pembiayaan yang diberikan oleh bank syariah menyebabkan kenaikan pada pertumbuhan ekonomi sektor riil.Pembiayaan berdasarkan prinsip syariah adalah penyediaan dana atau tagihan yang dipersamakan dengan dengan hal tersebut sesuai kesepakatan antara pihak bank dengan pihak lain yang mengharuskan pihak debitur untuk mengembalikan dana sesuai tagihan pada jangka waktu tertentu dengan bagi hasil.

Hasil penelitian atas pembiayaan yang diberikan berpengaruh terhadap pertumbuhan ekonomi sesuai dengan teori Schumpeter yang berkesinambungan dengan teori fungsi produksi.Teori Schumpeter pada hipotesis finance-led growth atau supply-leading view menunjukkan bahwa sektor keuangan mendorong pertumbuhan ekonomi. Pada perbankan syariah dorongan terhadap pertumbuhan ekonomi dilakukan melalui fungsi intermediasi bank yang menyalurkan dana hasil himpunan dari pihak yang memiliki kelebihan dana kepada pihak yang membutuhkan dana. Dana tersebut kemudian disalurkan oleh perbankan syariah berdasarkan sektor-sektor ekonomi yang ada di masyarakat.Berdasarkan jenis penggunaannya, pembiayaan tersebut kemudian dipergunakan untuk modal kerja, investasi dan konsumsi. Semakin banyak pembiayaan yang disalurkan untuk kegiatan produksi pada sektor riil yang ada di masyarakat akan berdampak pada pertumbuhan ekonomi.

Kassim (2016) dalam penelitiannya menjelaskan bahwa perbankan syariah di di Malaysia secara efektif melaksanakan peran intermediasi keuangan ke kegiatan investasi produktif.Kontribusi keuangan syariah terhadap ekonomi sektor riil dimungkinkan oleh prinsip penyertaan modal tertanam didalamnya.Instrumen pembiayaan bank syariah yang menjadi favorit masyarakat adalah pembiayaan murabahah (transaksi jual beli) yang merupakan pembiayaan konsumsi. Namun 
pembiayaan tertinggi setelahnya adalah musyarakah dan mudharabah yang memberikan pembiayaan jangka panjang pada sektor ekonomi produktif, tanpa bunga dengan pembagian keuntungan sesuai kesepakatan. Hubungan antara pemilik dana, pengusaha dan perbankan syariah berdasarkan konsep bagi hasil ini kemudian meningkatkan produktivitas di sektor-sektor ekonomi riil, sehingga sektor keuangan lebih stabil karena tidak ada risiko tingkat suku bunga yang kemudian meningkatkan pertumbuhan ekonomi. Pada prinsip bagi hasil, dasar penetapannya adalah laba bersih, sedangkan dalam sistem bunga, dasar penetapannya adalah jumlah pinjaman. Dalam prinsip bagi hasil, apabila pengusaha mengalami kerugian, maka tidak perlu memberikan tambahan kepada pemberi dana. Jadi usaha tetap bisa berjalan dan pengusaha tidak direpotkan dengan kewajiban untuk membayar tambahan.Sedangkan dalam sistem bunga, pembayaran bunga tetap harus dilakukan sesuai perjanjian tanpa mempertimbangkan usaha tersebut sedang untung atau merugi. Dalam hal ini, pengusaha dirugikan karena harus mencari dana lain untuk membayarkan bunganya.

Peningkatan pelayanan perbankan syariah dapat dilakukan dengan menambah jaringan kantor perbankan syariah. Penambahan ini diperlukan mengingat jumlah kantor perbankan syariah masih sangat minim dibandingkan bank konvensional. Peningkatan jumlah kantor bank syariah akan meningkatkan kualitas pelayanan dan mendorong inovasi produk dan jasa perbankan syariah.

\section{SIMPULAN}

Dana pihak ketiga berpengaruh positif terhadap pertumbuhan ekonomi sektor riil di Indonesia.Sektor keuangan dalam hal ini perbankan syariah selaku perantara keuangan berfungsi untuk mendistribusikan dana dari pihak yang memiliki dana berlebih ke pihak yang membutuhkan dana melalui sumber-sumber pendanaan yang efisien yang kemudian akan menggerakkan sektor-sektor ekonomi dan memacu pertumbuhan ekonomi.

Pembiayaan yang diberikan berpengaruh positif terhadap pertumbuhan ekonomi sektor riil di Indonesia.Semakin banyak pembiayaan yang disalurkan 
untuk kegiatan produksi pada sektor riil yang ada di masyarakat akan berdampak pada pertumbuhan ekonomi.

\section{SARAN}

Penelitian ini tidak menguji apakah ada hubungan kausalitas antar variabel yang digunakan. Uji kausalitas ini bermanfaat untuk melihat apakah ada pengaruh masa lalu dari suatu variabel terhadap variabel lain pada masa kini sesuai dengan kondisi yang terjadi. Peneliti memberikan saran agar pada penelitian selanjutnya untuk menambahkan pengujian kausalitas antar variabel untuk menguji hipotesis lain dari teori pertumbuhan ekonomi Schumpeter. 


\section{Daftar Pustaka}

Badan Pusat Statistik. Data Sensus Penduduk. 2010. Jakarta: Badan Pusat Statistik. (http://www.bps.go.id, diakses 17 April 2017)

Bank Indonesia.Statistik Perbankan Syariah Desember. 2016. Jakarta: Bank Indonesia. (http://www.bi.go.id, diakses 13 Maret 2017)

Budisantoso, Totok dan Nuritomo. 2015. Bank dan Perbankan Lain. Jakarta: Salemba Empat.

Fase, M \& Abma, R. 2003. Financial Environment and Economic Growth in Selected Asian Countries.Journal of Asian Economics, 14, 11-21.

Fatwa Fatwa Dewan Syariah Nasional Majelis Ulama Indonesia No. 1/DSNMUI/IV/2000

Fatwa Fatwa Dewan Syariah Nasional Majelis Ulama Indonesia No. 02/DSNMUI/IV/2006

Harrison, P., et. al. 1999. Finance and Growth: Theory and New Evidance. Federal Reserve Board Finance and Economics Discussion Paper.1999-35.

Kassim, S. 2016. Islamic Finance and Economic Growth: The Malaysian Experience. Global Finance Journal, 30, 66-76. https://doi.org/10.1016/j.gfj.2015.11.007

Kuncoro, Mudrajad. 2013. Mudah Memahami dan Menganalisis Indikator Ekonomi.Yogyakarta: UUPM STIM YKPN.

Nurhayati, Sri dan Wasilah. 2015. Akuntansi Syariah di Indonesia. Jakarta: Salemba Empat.

Undang-undang Nomor 21 Tahun 2008 tentang Perbankan Syariah.

Undang-undang Perbankan No. 10 Tahun 1998 tentang Perbankan

Yusof, R. M., \& Bahlous, M. 2013. Islamic Banking and Economic Growth in GCC \& East Asia Countries: A Panel Cointegration Analysis. Journal of Islamic Accounting and Business Research, 4(2), 151-172. https://doi.org/10.1108/JIABR-07-2012-0044 